\title{
BANK SYARIAH DI INDONESIA: ANALISIS PENGARUH RATA-RATA TINGKAT BAGI HASIL DEPOSITO DAN RATA-RATA TINGKAT SUKU BUNGA DEPOSITO TERHADAP JUMLAH DEPOSITO DAN JUMLAH NASABAH DEPOSITO PERIODE 2009-2014'
}

\author{
Aprilia Pratiwi \\ Program Studi Ekonomi Islam Fakultas Ekonomi dan Bisnis Universitas Airlangga \\ Email:aprilia.pratiwi-12@feb.unair.ac.id \\ Noven Suprayogi \\ Departemen Ekonomi Syariah Fakultas Ekonomi dan Bisnis Universitas Airlangga \\ Email: noven.suprayogi@feb.unair.ac.id
}

\begin{abstract}
:
This research aimed to determine the average profit-loss sharing level of deposit and the return level of deposit affect to total deposit and the quantity of Islamic banking customer in Indonesia, in time year 2009 until year 2014. The approach is a quantitative approach using VECM (Vector Error Correction Model) analytical techniques, to determine the effect of independent variable to dependent variable. The independent variable of this research is the average profit-loss sharing level of Islamic banking and the return level of deposit in conventional banking. While the dependent variable of this research is the total deposit and the quantity of Islamic banking customer in Indonesia. The result of this research showed that independent variable has a significant effect to total deposit in a long term, both simultaneous and partial. While in the quantity of customer, independent variable has no significant effect, both simultaneous and partial in a long term.
\end{abstract}

Keywords: profit-loss sharing, return, deposit, customer, Islamic banking

\section{PENDAHULUAN}

Dual-banking system yang mendukung hadirnya perbankan syariah dalam persaingan perbankan di Indonesia memberikan alternatif bagi masyarakat yang ingin menggunakan jasa perbankan namun tidak ingin bersentuhan dengan bunga bank atau riba. Bunga bank merupakan suatu hal yang dilarang dalam Islam karena di-qiyas-kan dengan riba. Sesuai dengan aturan Allah yang tercantum dalam surat Al-Baqarah ayat 278-279

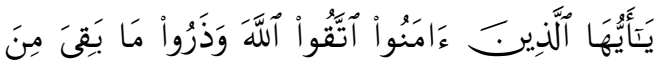

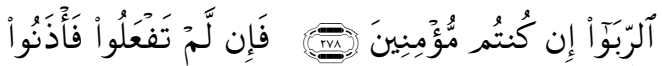

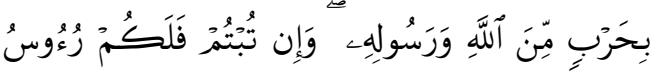

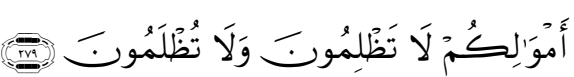

"Hai orang-orang yang beriman, bertakwalah kepada Allah dan tinggalkan sisa Riba (yang belum dipungut) jika kamu orang-orang yang beriman. Maka jika kamu tidak mengerjakan (meninggalkan sisa riba), Maka ketahuilah, bahwa Allah dan Rasul-Nya akan memerangimu. dan jika kamu bertaubat (dari pengambilan riba), Maka bagimu pokok hartamu; kamu tidak Menganiaya dan tidak (pula) dianiaya." (Q.S. Al Baqarah 278-279).

Hal mendasar yang membedakan perbankan konvensional dengan perbankan syariah adalah terletak pada mekanisme pengembalian dan pembagian keuntungan yang diberikan oleh nasabah kepada lembaga 1 Jurnal ini merupakan bagian dari skripsi yang ditulis oleh Aprilia Pratiwi, NIM: 041211432014, yang diuji pada bulan Mei 2016 
Pratiwi, et al/Jurnal Ekonomi Syariah Teori dan Terapan Vol. 4 No. 2 Februari 2017: 89-100; BANK SYARIAH DI INDONESIA: ANALISIS PENGARUH RATA-RATA TINGKAT BAGI HASIL DEPOSITO DAN RATA-RATA TINGKAT SUKU BUNGA DEPOSITO TERHADAP JUMLAH DEPOSITO DAN JUMLAH NASABAH DEPOSITO PERIODE 2009-2014

kevangan dan atau yang diberikan oleh lembaga keuangan kepada nasabah. Oleh karena itu, muncul istilah bunga dan bagi hasil (Muhammad, 2004:3).

Tingkat suku bunga pada bank konvensional dan tingkat bagi hasil pada bank syariah merupakan salah satu faktor penentu bagi masyarakat dalam memilih menggunakan jasa perbankan. Saat keuntungan yang ditawarkan oleh bank syariah lebih tinggi dibandingkan tingkat suku bunga yang diberikan oleh bank konvensional, maka kemungkinan nasabah yang semula merupakan nasabah bank konvensional akan menjadi nasabah bank syariah. Begitu juga sebaliknya, apabila tingkat suku bunga bank konvensional lebih besar dibandingkan tingkat keuntungan yang ditawarkan bank syariah maka tidak menutup kemungkinan nasabah yang semula merupakan nasabah bank syariah akan menjadi nasabah bank konvensional. Hal yang demikian tersebut dikenal dengan istilah displaced commercial risk. Displaced commercial risk terjadi ketika kinerja Bank Syariah mengalami performa yang buruk pada suatu periode sehingga Bank Syariah tidak dapat menghasilkan keuntungan yang memadai untuk di ditribusikan kepada para deposan. Bentuk keuntungan yang diberikan oleh Bank Syariah kepada deposan adalah bagi hasil.

Teori yang ada saat ini menyebutkan bahwa fluktuasi tingkat bagi hasil dan suku bunga bank umum diyakini menjadi salah satu faktor penentu bagi masyarakat dalam memilih menggunakan jasa perbankan terutama produk penghimpunan dana. Berikut adalah tabel daftar histori perkembangan rata-rata tingkat bagi hasil dan rata-rata suku bunga serta jumlah simpanan dan jumlah nasabah bank syariah tahun 2009 2014.

Tabel 1.

Perkembangan Rata-rata Tingkat Bagi Hasil dan Rata-rata Tingkat Suku Bunga serta Jumlah Deposito dan Jumlah Nasabah Deposito Tahun 2009-2014

\begin{tabular}{|c|c|c|c|c|}
\hline Tahum & $\begin{array}{c}\text { Rata-rata Tingkat } \\
\text { Bagi Hasil }\end{array}$ & $\begin{array}{c}\text { Rata-rata Suku } \\
\text { Bunga Deposito }\end{array}$ & $\begin{array}{c}\text { Jumlah } \\
\text { Deposito }\end{array}$ & $\begin{array}{c}\text { Jumlah Nasabah } \\
\text { Deposito }\end{array}$ \\
\hline $\mathbf{2 0 0 9}$ & $8,06 \%$ & $9,57 \%$ & 29.595 Milyar & 150.348 Unit \\
\hline $\mathbf{2 0 1 0}$ & $6,97 \%$ & $6,93 \%$ & 44.072 Miliar & 186.400 Unit \\
\hline $\mathbf{2 0 1 1}$ & $6,84 \%$ & $7,00 \%$ & 70.806 Miliar & 224.217 Unit \\
\hline $\mathbf{2 0 1 2}$ & $6,55 \%$ & $6,00 \%$ & 84.732 Miliar & 317.864 Unit \\
\hline $\mathbf{2 0 1 3}$ & $5,54 \%$ & $6,28 \%$ & 107.812 Miliar & 356.422 Unit \\
\hline $\mathbf{2 0 1 4}$ & $6,98 \%$ & $8,59 \%$ & 135.629 Miliar & 269.619 Unit \\
\hline
\end{tabular}

Berdasarkan tabel 1. dapat dilihat bahwa data bank syariah di Indonesia pada tahun 2009 hingga 2014 tidak mencermikan teori yang ada tersebut. Fluktuasi tingkat bagi hasil bank syariah di Indonesia tidak sepenuhnya mempengaruhi jumlah deposito dan jumlah nasabah deposito bank syariah. Meskipun tingkat bagi hasil bank syariah mengalami kenaikan dan penurunan pada tahun 2009 hingga 2014 jumlah deposito bank syariah terus mengalami peningkatan. Hal yang sama juga terjadi pada jumlah nasabah deposito perbankan syariah yang terus meningkat dari tahun 2009 sampai 2013. Terdapat hal yang menarik ditemukan pada taun 2014 dimana bagi hasil meningkat namun jumlah nasabah deposito perbankan syariah di Indonesia justru menurun. 
Pratiwi, et al/Jurnal Ekonomi Syariah Teori dan Terapan Vol. 4 No. 2 Februari 2017: 89-100; BANK SYARIAH DI INDONESIA: ANALISIS PENGARUH RATA-RATA TINGKAT BAGI HASIL DEPOSITO DAN RATA-RATA TINGKAT SUKU BUNGA DEPOSITO TERHADAP JUMLAH DEPOSITO DAN JUMLAH NASABAH DEPOSITO PERIODE 2009-2014

Meskipun tingkat bagi hasil tidak dapat sepenuhnya mempengaruhi jumlah nasabah bank syariah di Indonesia, namun perbedaan rata-rata tingkat bagi hasil dan rata-rata suku bunga tersebut membuat adanya segmentasi konsumen sebagai pengguna jasa perbankan.

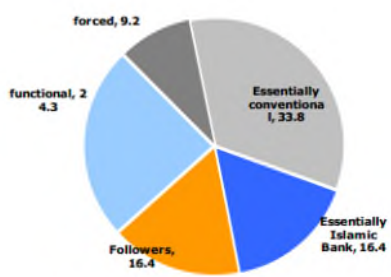

Hasil Survey MDSP tahun 2007

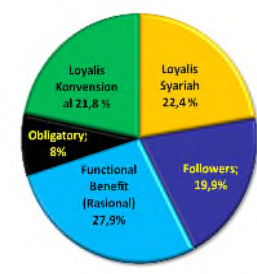

Hasil Survey MDSP tahun 2010
Gambar 1.

Profil Segmen Nasabah Perbankan Syariah

(Evaluasi MDSP tahun 2007 dan 2010)

Segmentasi konsumen tersebut juga dapat mempengaruhi perkembangan bank syariah di Indonesia. Berdasarkan data perkembangan perbankan syariah nasional oleh $\mathrm{Bl}$, total aset bank syariah hingga akhir Maret 2012 mencapai Rp. 152,3 triliun. Dalam 5 tahun terakhir rata-rata volume usaha bank syariah bertumbuh sebesar $40.2 \%$ per tahun. Jauh melebihi pertumbuhan industri perbankan nasional yang berkisar 15-20\% per tahun. Keadaan tersebut diharapkan market share perbankan syariah, yang saat ini bertumbuh sekitar $4,13 \%$ dapat mencapai 15 sampai dengan $20 \%$ dalam periode 10 - 15 tahun mendatang.

Berdasarkan uraian yang telah dijelaskan, maka peneliti merumuskan masalah penelitian sebagai berikut: Apakah tingkat rata-rata bagi hasil bank syariah dan suku bunga bank konvenional beperngaruh terhdap jumlah deposito bank syariah di Indonesia; serta Apakah tingkat rata-rata bagi hasil bank syariah dan suku bunga bank konvenional beperngaruh terhdap jumlah nasabah deposito bank syariah di Indonesia?

\section{LANDASAN TEORI}

Terdapat teori pada bank konvensional yang menjelaskan pengaruh tingkat suku bunga terhadap jumlah simpanan yang ada di bank konvensional yang dijadikan sebagai landasan bagi perbankan syariah dalam menjelaskan pengaruh bagi hasil terhadap jumlah simpanan pada perbankan syariah. Teori tersebut adalah teori ekonomi klasik tentang tingkat bunga. Teori ini menjelaskan bahwa tabungan merupakan fungsi dari tingkat bunga, artinya semakin besar tingkat bunga, maka akan semakin mendorong keinginan masyarakat untuk menabung (Nopirin, 2002: 70).

Pada tingkat suku bunga yang lebih tinggi masyarakat akan terdorong untuk mengorbankan atau mengurangi pengeluaran konsumsi untuk menambah fungsi tabungannya.

Berbeda dengan Klasik, Keynes mempunyai pandangan yang berbeda dengan tingkat bunga. Menurut Keynes tingkat bunga ditentukan oleh penawaran dan permintaan akan vang (ditentukan dalam pasar vang). Uang merupakan salah satu bentuk kekayaan yang dipunyai seseorang (portofolio) seperti halnya kakayaan dalam bentuk tabungan di bank, saham, atau surat berharga lainnya (Nopirin, 2002: 91). Keputusan masayarakat mengenai bentuk 
Pratiwi, et al/Jurnal Ekonomi Syariah Teori dan Terapan Vol. 4 No. 2 Februari 2017: 89-100; BANK SYARIAH DI INDONESIA: ANALISIS PENGARUH RATA-RATA TINGKAT BAGI HASIL DEPOSITO DAN RATA-RATA TINGKAT SUKU BUNGA DEPOSITO TERHADAP JUMLAH DEPOSITO DAN JUMLAH NASABAH DEPOSITO PERIODE 2009-2014

susunan/komponen kekayaan yang diwujudkan dalam bentuk vang kas, tabungan atau surat berharga tersebut yang akan menentukan tinggi rendahnya tingkat bunga. Asumsi Teori Keynes adalah dasar pemilikan bentuk penyimpangan kekayaan adalah perilaku masyarakat yang selalu menghindari resiko dan ingin memaksimumkan keuntungan.

Hubungan kedua teori tersebut jika dikaitkan dengan perilaku konsumen, kedua teori tentang tingkat bunga dapat mewakili teori yang menjelaskan pengaruh tingkat bagi hasil dan tingkat bunga terhadap jumlah nasabah yang ada di bank syariah. Hal ini disebabkan karena konsumen melihat bahwa tingkat suku bunga simpanan yang diberikan bank konvensional ataupun tingkat bagi hasil yang diberikan bank syariah adalah sama-sama merupakan imbal jasa yang diberikan pihak bank kepada nasabah/deposan atas vang yang disimpankan di bank. Semakin tinggi tingkat bunga atau bagi hasil yang diberikan semakin besar keinginan masyarakat untuk menabung atau masyarakat akan terdorong untuk mengorbankan pengeluaran guna menambah besarnya tabungan.

\section{METODE PENELITIAN}

Penelitian ini meneliti pengaruh bagi hasil deposito pada perbankan syariah dan suku bunga deposito pada bank konvensional terhadap jumlah deposito dan jumlah nasabah perbankan syariah di Indonesia. Pengujian dilakukan dengan metode Vector Error Correction Model
(VECM), karena alat yang digunakan untuk mengolah data yang terkointegrasi adalah VECM.

\section{Definisi Operasional Variabel Jumlah Deposito}

Jumlah deposito dalam penelitian ini merupakan keseluruhan jumlah deposito nasabah bank syariah yang berakadkan mudharabah periode 20092014. Data diperoleh dari laporan statistik perbankan syariah melalui website resmi OJK (www.ojk.go.id) dan BI (www.bi.go.id).

\section{Jumlah Nasabah}

Jumlah nasabah dalam penelitian ini merupakan jumlah keseluruhan nasabah bank syariah baik individu maupun non individu pada bank syariah di Indonesia periode 2009-2014. Data diperoleh dari laporan statistik perbankan syariah melalui website resmi OJK (www.ojk.go.id) dan BI (www.bi.go.id).

\section{Tingkat Rata-rata Bagi Hasil}

Bagi hasil adalah rata-rata ekuivalen tingkat imbalan/bagi hasil/fee/bonus Bank Syariah yang dinyatakan dalam presentase. Bagi hasil yang digunakan dalam penelitian ini adalah rata-rata tingkat ekuivalen bagi hasil deposito bank syariah yang terdiri dari deposito 1 bulan, 3 bulan, 6 bulan, dan 12 bulan di Indonesia periode 20092014. Data diperoleh dari laporan statistik perbankan syariah melalui website resmi OJK (www.ojk.go.id) dan BI (www.bi.go.id).

\section{Tingkat Rata-rata Suku Bunga}


Pratiwi, et al/Jurnal Ekonomi Syariah Teori dan Terapan Vol. 4 No. 2 Februari 2017: 89-100; BANK SYARIAH DI INDONESIA: ANALISIS PENGARUH RATA-RATA TINGKAT BAGI HASIL DEPOSITO DAN RATA-RATA TINGKAT SUKU BUNGA DEPOSITO TERHADAP JUMLAH DEPOSITO DAN JUMLAH NASABAH DEPOSITO PERIODE 2009-2014

Rata-rata tingkat suku bunga yang digunakan dalam penelitian ini adalah rata-rata tingkat suku bunga deposito yang terdiri dari deposito 1 bulan, 3 bulan, 6 bulan, dan 12 bulan bank konvensional di Indonesia periode 2010-2014 yang dinyatakan dalam bentuk presentase. Data diperoleh dari laporan statistik perbankan Indonesia melalui website resmi BI (www.bi.go.id).

\section{Jenis Data}

Jenis data yang digunakan adalah data sekunder, yaitu sumber data penelitian yang diperoleh peneliti secara tidak langsung melalui media perantara (diperoleh dan dicatat pihak lain), umumnya berupa bukti, catatan atau laporan historis yang telah tersusun dalam arsip (data documenter). Data yang digunakan dalam penelitian ini berupa data time series atau deret waktu. Data yang digunakan mulai Januari 2009 sampai dengan Desesmber 2014.

\section{Metode Pengumpulan Data}

Metode yang digunakan peneliti dalam memperoleh data ialah metode dokumentasi yaitu dengan melakukan pencatatan atau mengumpulkan catatan-catatan yang menjadi bahan penelitian terutama Laporan Statistik Perbankan Syariah dari website resmi OJK (untuk variabel rata-rata tingkat bagi hasil deposito, jumlah deposito, dan jumlah nasabah), dan Laporan Statistik Perbankan Indonesia (untuk variabel ratarata tingkat suku bunga deposito bank umum konvensional) yang diperoleh dari website resmi BI.

\section{Populasi dan Sampel}

Populasi yang digunakan dalam penelitian ini adalah Bank Umum Syariah secara keseluruhan yang terdapat pada Laporan Statistik Perbankan Syariah periode Januari 2009 sampai dengan Desember 2014. Teknik sampel yang digunakan adalah sampling jenuh dimana semua anggota populasi anggota populasi digunakan sebagai sampel.

\section{Model Analisis}

Metode yang digunakan dalam penelitian ini adalah metode Vector Error Correction Model (VECM). VECM merupakan bentuk VAR yang terestrksi. Restriksi tambahan ini harus diberikan karena keberadaan bentuk data yang tidak stasioner namun terkointegrasi. VECM kemudian memanfaatkan informasi restriksi kointegrasi kedalam spesifikasinya, karena itulah VECM sering disebut sebagai design VAR bagi series nonstasioner yang memiliki hubungan kointegrasi. VECM merupakan suatu model analisis ekonometrika yang dapat digunakan untu mengtahui tingkah laku jangka pendek dari suatu variabel terhadap jangka panjangnya, akibat adanya shock yang permanen (Kostov dan Linglard, 2000) dalam Setianto dan Ajija (2011: 189).

\section{HASIL DAN PEMBAHASAN}

\section{Uji Stasioneritas Data}

Dalam menganalisis data runtun waktu atau time series perlu dilakukan uji stasioneritas. Suatu data dikatakan stasioner apabila data tersebut tidak mengandung akar-akar unit (unit root) dengan kata mean, variance, dan 
Pratiwi, et al/Jurnal Ekonomi Syariah Teori dan Terapan Vol. 4 No. 2 Februari 2017: 89-100; BANK SYARIAH DI INDONESIA: ANALISIS PENGARUH RATA-RATA TINGKAT BAGI HASIL DEPOSITO DAN RATA-RATA TINGKAT SUKU BUNGA DEPOSITO TERHADAP JUMLAH DEPOSITO DAN JUMLAH NASABAH DEPOSITO PERIODE 2009-2014

covariance konstan sepanjang waktu. Uji unit root dilakukan dengan menggunakan metode Augmented Dickey Fuller (ADF) dengan cara membandingkan nilai ADF statistik dengan nilai kritis Mackinnon $5 \%$. Apabila pengujian pada tingkat level nilai ADF statitik lebih besar dari pada nilai kritis Mackinnon maka data tersebut stasioner karena tidak mengandung unit root. Sebaliknya, apabila pada tingkat level data tersebut mengadung unit root dan tidak stasioner maka harus dilakukan differencing data, yakni mengurangi data dengan data periode sebelumnya sehingga akan diperoleh data data dalam bentuk first difference.

Tabel 2.Hasil

Uji Stasioneritas tingkat First

Difference

\begin{tabular}{|ccc|}
\hline Variabel & Prob.* & Keterangan \\
\hline Suku Bunga(SB) & 0.0002 & Stasioner \\
\hline Bagi Hasil (BH) & 0.0000 & Stasioner \\
\hline Jumlah Nasabah (Ns) & 0.0000 & Stasioner \\
\hline Jumlah Deposito (De) & 0.0000 & Stasioner \\
\hline
\end{tabular}

\section{Uji Lag Length Optimal}

Penentuan jumlah lag ditentukan oleh kriteria informasi yang direkomendasikan oleh Final Prediction Error (FPE), Aike Information Criterion (AIC), Schwarz Criterion (SC), dan Hannan-Quinn (HQ) dengan tanda bintang yang menunjukkan lag optimal. Berdasarkan uji yang dilakukan, lag optimal yang disarankan ialah lag dua dengan tanda $(*)$.

Tabel 3.

Hasil Uji Lag Length terhadap Deposito

\section{Error! Not a valid link.}

Tabel 4.

Hasil Uji Lag Length terhadap Nasabah Error! Not a valid link.Uji Kointegrasi

Uji kointegrasi dilakukankan dengan menggunakan metode Johansen's Multivariate Cointegration Test dengan cara membandingkan nilai trace statistik dengan nilai kritis $5 \%$ dan membandingkan nilai Max-Eigen dengan nilai kritis $5 \%$. Apabila nilai trace statistik lebih besar dari pada nilai kritis dan nilai Max-Eigen lebih besar dari nilai kritis maka data tersebut terkointegrasi. Data yang terkointegrasi menunjukkan adanya hubungan jangka panjang antar variabel dan menunjukkan sinyal yang benar untuk menggunakan metode VECM. Berdasarkan uji yang dilakukan nilai Trace statistik yang diperoleh lebih besar dari nilai kritis $5 \%$. Begitu juga dengan nilai Max-Eigen yang diperoleh, lebih besar dari nilai kritis $5 \%$.

Tabel 5.

Johansen Cointegration Test Summary terhadap Deposito

\begin{tabular}{|lllll|}
\hline \multicolumn{5}{|c|}{ Unrestricted Cointegration Rank test (Trace) } \\
\hline Hypothesized & Trace & 0.05 \\
\hline No. of CE(s) & Eigenvalue & Statistic & Critical Value & Prob.** \\
\hline None * & 0.376205 & 42.58512 & 24.27596 & 0.0001 \\
\hline At most 1 * & 0.098716 & 10.49365 & 12.32090 & 0.0993 \\
\hline At most 2 * & 0.049136 & 3.426101 & 4.129906 & 0.0761 \\
\hline \multicolumn{5}{|c|}{ Trace test indicates 1 cointegrating eqn(s) at the 0.05 level } \\
\hline \multicolumn{5}{|c|}{} \\
\hline Unrestricted Cointegration Rank Test (Maximum Eigenvalue) \\
\hline Hypothesized & Max-Eigen & 0.05 \\
\hline No. of CE(s) & Eigenvalue & Statistic & Critical Value & Prob.** \\
\hline None * & 0.376205 & 32.09148 & 17.79730 \\
\hline At most 1 * & 0.098716 & 7.067546 & 11.22480 & 0.0002 \\
\hline At most 2 & 0.049136 & 3.426101 & 4.129906 & 0.2437 \\
\hline Max-eigenvalue test indicates 1 cointegrating eqn(s) at the 0.05 level \\
\hline
\end{tabular}

Tabel 6. 
Pratiwi, et al/Jurnal Ekonomi Syariah Teori dan Terapan Vol. 4 No. 2 Februari 2017: 89-100; BANK SYARIAH DI INDONESIA: ANALISIS PENGARUH RATA-RATA TINGKAT BAGI HASIL DEPOSITO DAN RATA-RATA TINGKAT SUKU BUNGA DEPOSITO TERHADAP JUMLAH DEPOSITO DAN JUMLAH NASABAH DEPOSITO PERIODE 2009-2014

Johansen Cointegration Test Summary terhadap Nasabah

Error! Not a valid link. Estimasi VECM

Berdasarkan tabel estimasi VECM dalam jangka panjang,

Tabel 7.

Hasil Estimasi VECM terhadap Deposito Error! Not a valid link.

Tabel 8.

Hasil Estimasi VECM terhadap Nasabah

\begin{tabular}{|cc|}
\hline Cointegrating Eq: & CointEq1 \\
\hline DLN_NS(-1) & 1.000000 \\
\hline DBAGI_HASIL(-1) & -0.003082 \\
& $(0.01332)$ \\
& {$[-0.23136]$} \\
\hline DSUKU_BUNGA(-1) & 0.053805 \\
& $(0.06164)$ \\
& {$[0.87285]$} \\
\hline C & -0.009345 \\
\hline
\end{tabular}

\section{Fungsi Impulse Respon}

Fungsi impulse respon digunakan untuk mengetahui pengaruh shock dalam perekonomian. Fungsi impulse respon menggambarkan tingkat laju shock dari sebuah variabel terhadap variabel lainnya dalam rentang waktu tertentu sehingga bisa dilihat sejauh mana pengaruh shock dari satu varibel terhadap variabel lainnya sampai hilang dan kembali pada titik keseimbangan.

\section{Gambar 2.}

Hasil Uji Impulse Response
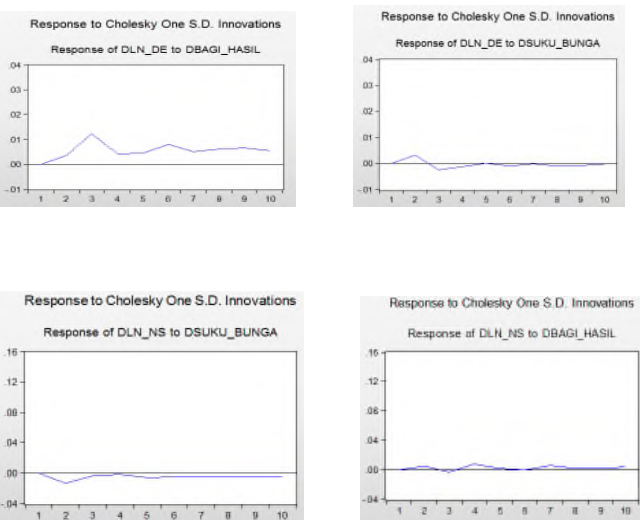

\section{Variance Decompocition}

Variance Decompositions disebut juga forecast error variance decomposition merupakan perangkat pada model VAR/VECM yang akan memisahkan variasi dari sejumlah variabel yang diestimasi menjadi komponenkomponen shock atau menjadi variabel innovation, dengan asumsi bahwa variabel-variabel innovation tidak saling berkolerasi. Metode ini akan memberikan informasi mengenai proporsi dari pergerakan pengaruh shock pada sebuah variabel terhadap shock variabel lain dalam periode waktu tertentu.

Tabel 9.

Hasil Uji Variance Decompocition terhadap variabel Deposito

\begin{tabular}{|rcccc|}
\hline Periode & S.E & DLN DE & DBAG_HASIL DSUKU_BUNGA \\
\hline $\mathbf{1}$ & 0.038401 & 100.0000 & 0.000000 & 0.000000 \\
\hline $\mathbf{2}$ & 0.040637 & 96.75243 & 2.993343 & 0.254227 \\
\hline $\mathbf{3}$ & 0.044805 & 90.09850 & 9.242766 & 0.658734 \\
\hline $\mathbf{4}$ & 0.050050 & 91.75697 & 7.714230 & 0.528800 \\
\hline $\mathbf{5}$ & 0.052726 & 91.67754 & 7.845176 & 0.477284 \\
\hline $\mathbf{6}$ & 0.056155 & 90.73933 & 8.810462 & 0.450205 \\
\hline $\mathbf{7}$ & 0.059414 & 90.78122 & 8.811592 & 0.407188 \\
\hline $\mathbf{8}$ & 0.062093 & 90.71201 & 8.909235 & 0.378752 \\
\hline $\mathbf{9}$ & 0.064930 & 90.58408 & 9.061633 & 0.354287 \\
\hline $\mathbf{1 0}$ & 0.067626 & 90.51133 & 9.157680 & 0.330988 \\
\hline
\end{tabular}

Tabel 10.

Hasil Uji Varianve Decompocition terhadap variabel Nasabah Deposito

\begin{tabular}{|rcccc|}
\hline Periode & S.E & DLN_NS & DBAGI_HASIL & DSUKU_BUNGA \\
\hline $\mathbf{1}$ & 0.121478 & 100.0000 & 0.000000 & 0.000000 \\
\hline $\mathbf{2}$ & 0.123962 & 98.69698 & 0.155570 & 1.147455 \\
\hline $\mathbf{3}$ & 0.125098 & 98.57385 & 0.230524 & 1.195624 \\
\hline $\mathbf{4}$ & 0.125825 & 98.17374 & 0.623730 & 1.202525 \\
\hline $\mathbf{5}$ & 0.125970 & 97.95141 & 0.643022 & 1.405573 \\
\hline $\mathbf{6}$ & 0.126094 & 97.78102 & 0.642440 & 1.576544 \\
\hline $\mathbf{7}$ & 0.126298 & 97.46905 & 0.842910 & 1.688043 \\
\hline $\mathbf{8}$ & 0.126374 & 97.36121 & 0.853354 & 1.785435 \\
\hline $\mathbf{9}$ & 0.126525 & 97.17903 & 0.875051 & 1.945923 \\
\hline $\mathbf{1 0}$ & 0.126668 & 96.95989 & 0.962960 & 2.077154 \\
\hline
\end{tabular}

\section{Uji Hipotesis}

Berdasarkan hasil analisis yang dilakukan bahwa bagi hasil dan suku bunga berpengaruh signifikan terhadap 
Pratiwi, et al/Jurnal Ekonomi Syariah Teori dan Terapan Vol. 4 No. 2 Februari 2017: 89-100; BANK SYARIAH DI INDONESIA: ANALISIS PENGARUH RATA-RATA TINGKAT BAGI HASIL DEPOSITO DAN RATA-RATA TINGKAT SUKU BUNGA DEPOSITO TERHADAP JUMLAH DEPOSITO DAN JUMLAH NASABAH DEPOSITO PERIODE 2009-2014

deposito dalam jangka panjang. Hal ini dapat dilihat dari nilai t-statistik yang lebih besar dari t-tabel. Sedangkan bagi hasil dan suku bunga tidak berpengaruh signifikan terhadap nasabah deposito dalam jangka panjang. Hal ini dapat dilihat dari nilai nilai t-statistik yang lebih kecil dari t-tabel.

\section{Pembahasan}

Dari hasil estimasi VECM yang dilakukan, dalam jangka panjang variabel bagi hasil dan suku bunga signifikan mempengaruhi deposito secara simultan. Hal ini sesuai dengan teori tingkat bunga dimana teori ini menjelaskan bahwa tabungan merupakan fungsi dari tingkat bunga, artinya semakin besar tingkat bunga, maka akan semakin mendorong keinginan masyarakat untuk menabung (Nopirin, 2002: 70). Secara parsial bagi hasil berpengaruh signifikan negatif terhadap jumlah deposito. Ketika bagi hasil bank syariah mengalami penurunan, jumlah deposito bank syariah justru mengalami peningkatan. $\mathrm{Hal}$ ini dimungkinkan dalam prinsip ekonomi Islam dimana return bukan merupakan faktor utama nasabah dalam menabung atau berinvestasi pada deposito perbankan syariah. Terdapat faktor syariah (kepatuhan pada ketentuan syariah) dan faktor sosial (kemaslahatan umat) yang juga menjadi pertimbangan nasabah. Terkait dengan motif nasabah dalam menggunakan jasa perbankan syariah di Indonesia, Hasil kajian model bisnis perbankan syariah (2010) mengungkapkan bahwa presentasi jumlah konsumen dari segmen nasabah essentially Islamic banking meningkat meningkat $6 \%$ menjadi $22,4 \%$ jika dibandingkan dengan tahun 2007. Hasil kajian ini didukung oleh penelitian Ismal (2009) dalam kajian model bisnis perbankan syariah 2012 yang menganalisis segementasi deposan berdasarkan motivasi mendepositokan vang dan menemukan bahwa mayoritas deposan pengguna perbankan syariah menggunakan bank syariah karena motif prinsip syariah.

Disisi lain, hasil analisis yang menunjukkan pengaruh negatif dari tingkat bagi hasil terhadap jumah deposito adalah, saat bagi hasil perbankan syariah mengalami peningkatan justru deposito perbankan syariah mengalami penurunan. Hal ini terjadi karena masyarakat memiliki alternatif pilihan dalam berinvestasi pada sektor keuangan maupun investasi pada sektor riil. Investasi pada sektor riil memiliki return yang lebih stabil jika dibandingkan dengan sektor keuangan dalam jangka panjang. Ketika bagi hasil perbankan syariah tinggi, hal ini mengindikasikan bahwa keadaan bisnis perbankan syariah dalam keadaan baik yang juga menjadi parameter keadaan perekonomian yang baik, yang dimungkinkan untuk terciptanya iklim investasi yang kondusif.

Badan koordinasi penanaman modal (BPKM) mencatat realisasi penanaman modal dalam negeri pada tahun 2014 mencapai Rp 156,126.2 milyar, meningkat sebesar $\quad 157 \%$ jika 
Pratiwi, et al/Jurnal Ekonomi Syariah Teori dan Terapan Vol. 4 No. 2 Februari 2017: 89-100; BANK SYARIAH DI INDONESIA: ANALISIS PENGARUH RATA-RATA TINGKAT BAGI HASIL DEPOSITO DAN RATA-RATA TINGKAT SUKU BUNGA DEPOSITO TERHADAP JUMLAH DEPOSITO DAN JUMLAH NASABAH DEPOSITO PERIODE 2009-2014

dibandingkan tahun 2010. Menurut data BPKM investasi dalam negeri pada sektor Listrik, Gas, dan Air adalah yang paling besar pada tahun 2014 mencakup 68 proyek dengan nilai investasi Rp. 36,296.8 milyar. Kemudian disusul investasi bidang makanan yang terdiri atas 320 proyek dengan nilai Rp. 19,596.4 milyar. Sementara investasi pada sektor konstruksi terdapat 27 proyek dengan nilai Rp. 12,097.6 milyar dan untuk sektor transportasi, gudang, dan kominikasi berjumlah 46 proyek dengan nilai Rp. 15,715.0 milyar (www.bpkm.go.id). Nilai investasi pada sektor rill memiliki jumlah yang lebih besar jika dibandingkan nilai investasi pada sektor keuangan khususnya deposito perbankan syariah di Indonesia.

Perspektif ekonomi Islam menjelaskan hubungan yang berkaitan dengan investasi bahwa, dalam usaha untuk memperoleh keuntungan, seorang muslim dihadapkan pada kondisi ketidakpastian terhadap apa yang akan terjadi. Tidak ada yang bisa memastikan apa yang akan terjadi dari hasil investasi tersebut, apakah untung atau rugi. Hal ini merupakan sunnatullah atau ketentuan Allah SWT seperti yang terdapat pada Q.S Luqman ayat 34 :

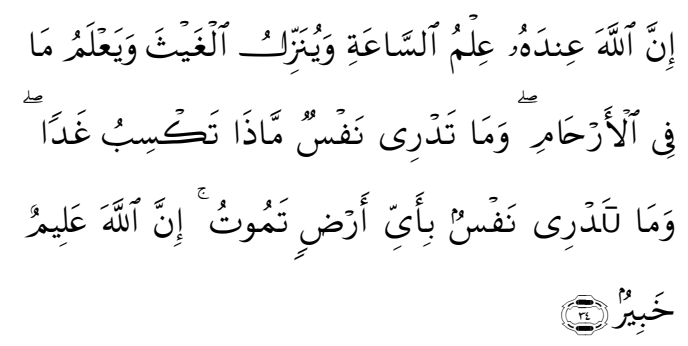

"Sesungguhnya Allah, hanya pada sisi-Nya sajalah pengetahuan tentang hari Kiamat; dan Dia-lah yang menurunkan hujan, dan mengetahui apa yang ada dalam rahim. dan tiada seorangpun yang dapat mengetahui (dengan pasti) apa yang akan diusahakannya besok". (Q.S Luqman: 34).

Sedangkan hubungan suku bunga bank konvensional dengan deposito bank syariah secara parsial adalah positif dalam jangka panjang. Hal ini sesuai dengan teori utilitas, yang mengatakan bahwa hubungan suku bunga bank konvensional dengan deposito bank syariah adalah ketika suku bunga bank konvensional meningkat dan diimbangi dengan kinerja bank syariah yang baik maka akan meningkatkan produktiitas pada bank syariah, sehingga nasabah akan cenderung memilih menggunakan produk bank syariah yang akan membuat jumlah deposito bank syariah juga meningkat. Namun, teori utilitas juga tidak akan berlaku, apabila suku bunga bank konvensional meningkat tetapi kinerja bank syariah sedang tidak baik, sehingga bagi hasil pada perbankan syariah juga tidak akan meningkat dan mengakibatkan jumlah deposito pada bank syariah menurun.

Berdasarkan hasil estimasi VECM yang telah dilakukan, variabel bagi hasil dan suku bunga tidak mempengaruhi nasabah baik secara simultan maupun secara parsial dalam jangka panjang. Hal ini sesuai dengan penelitian yang dilakukan oleh Bl yang bekerjasama dengan IPB pada tahun 2004 dalam meneliti potensi, preferensi, dan perilaku 
Pratiwi, et al/Jurnal Ekonomi Syariah Teori dan Terapan Vol. 4 No. 2 Februari 2017: 89-100; BANK SYARIAH DI INDONESIA: ANALISIS PENGARUH RATA-RATA TINGKAT BAGI HASIL DEPOSITO DAN RATA-RATA TINGKAT SUKU BUNGA DEPOSITO TERHADAP JUMLAH DEPOSITO DAN JUMLAH NASABAH DEPOSITO PERIODE 2009-2014

masyarakat terhadap bank syariah di wilayah Kalimantan Selatan. Dalam penelitian tersebut dijelaskan bahwa kesesuaian dengan ajaran agama, kedekatan lokasi/aksesibilitas, profesionalisme pelayanan, kredibilitas, dan fasilitas lebih menjadi alasan-alasan utama yang menyebabkan masyarakat dalam memilih jasa perbankan syariah. Sedangkan, tingkat return yang diberikan oleh perbankan syariah bukan merupakan pertimbangan utama dalam mengunakan jasa perbankan syariah. Hasil penelitian tersebut didukung oleh penelitian Metawa dan Almossawi dalam Fatma (2008) yang menyatakan bahwa faktor utama nasabah mempertahankan hubungannya atau tetap loyal pada bank syariah adalah ketaatan mereka terhadap prinsip-prinsip syariah. Nasabah memutuskan untuk tetap mempertahankan bank syariah berkaitan dengan masalah keimanan dan kayakinan terhadap pengharaman riba bagi umat Islam.

Kaitannya dengan resiko displaced commercial risk (DCR) yang dimiliki oleh perbankan syariah menunjukkan bahwa resiko DCR pada perbankan syariah bukan merupakan berpindahnya nasabah bank syariah ke nasabah bank konvensional atau sebaliknya, melainkan berpindahnya dana dari nasabah tersebut. Terlihat dari jumlah deposito yang terus naik dan jumlah nasabah yang berfluktuasi terhadap perubahan ataupun perkembangan bagi hasil perbankan syariah. Hal ini dimungkinkan terjadi mengingat usaha perbankan dalam menjaga atau mempertahankan nasabahnya. Perbankan tidak akan mudah memberikan izin bagi nasabah untuk menutup rekeningnya dan bahkan cenderung menyulitkan. Ini dilakukan semata-mata untuk mempertahankan nasabahnya agar tidak keluar dari bank tersebut dan berpindah ke bank lain.

\section{KESIMPULAN}

Berdasarkan pada nilai analisis dan pengujian hipotesis, maka dapat diambil beberapa kesimpulan sebagai berikut:

1. Dari hasil estimasi VECM tingkat bagi hasil secara parsial berpengaruh signifikan negatif terhadap jumlah deposito dalam jangka panjang pada perbankan syariah di Indonesia.

2. Dari hasil estimasi VECM tingkat suku bunga secara parsial berpengaruh signifikan positif terhadap jumlah deposito dalam jangka panjang pada perbankan syariah di Indonesia.

3. Dari hasil estimasi VECM tingkat bagi hasil secara parsial tidak berpengaruh signifikan terhadap jumlah nasabah dalam jangka panjang pada perbankan syariah di Indonesia.

4. Dari hasil estimasi VECM tingkat suku bunga secara parsial tidak berpengaruh signifikan terhadap jumlah nasabah dalam jangka panjang pada perbankan syariah di Indonesia.

5. Dari hasil estimasi VECM tingkat bagi hasil dan suku bunga secara simultan berpengaruh signifikan terhadap 
Pratiwi, et al/Jurnal Ekonomi Syariah Teori dan Terapan Vol. 4 No. 2 Februari 2017: 89-100; BANK SYARIAH DI INDONESIA: ANALISIS PENGARUH RATA-RATA TINGKAT BAGI HASIL DEPOSITO DAN RATA-RATA TINGKAT SUKU BUNGA DEPOSITO TERHADAP JUMLAH DEPOSITO DAN JUMLAH NASABAH DEPOSITO PERIODE 2009-2014

jumlah deposito dalam jangka panjang pada perbankan syariah di Indonesia.

6. Dari hasil estimasi VECM tingkat bagi hasil dan suku bunga secara simultan tidak berpengaruh signifikan terhadap jumlah nasabah dalam jangka panjang pada perbankan syariah di Indonesia.

\section{DAFTAR PUSTAKA}

Al-Quran dan Terjemahannya. 2002. Departemen Agama Republik Indonesia. Surabaya: Duta IImu Surabaya.

Ajija, Shocrul, Sari, Dyah, W., Setianto, Rahmat, H., dan Martha R. Primanti. 2011. Cara Cerdas Menguasai Eviews. Jakarta: Salemba Empat.

Al Arif, M. Nur Rianto. 2011. Ze Effect of Macroeconomics Variable to Ze Profit Sharing Yield Decision in Indonesia Islamic Banking Industry, Economic Journal of Emerging Markes, Faculty of Economic Universitas Islam Indonesia Volume 3, Issue 3, December 2011, page 235-244

Alwi, Hasan. 2003. Kamus Besar Bahasa Indonesia. Jakarta: Balai Pustaka.

Amelia, Fatma. 2009. Analisis Motivasi Masyarakat Menabung Di Perbankan Syariah Studi Kasus Kota Padang. Skripsi tidak diterbitkan. Padang: Universitas Andalas

Antonio, Muhammad Syafi'i. 2001. Bank Syariah dari Teori ke Praktik. Jakarta: Gema Insani

Anshori, Muslich dan Sri Iswati. 2009. Metodologi Penelitian Kuantitatif. Surabaya: Airlangga University Press

Ariefianto, Moch. Doddy. 2012. Ekonometrika: Esensi dan Aplikasi dengan menggunakan EVIEWS. Jakarta: Penerbit Erlangga

Bank Indonesia dan Institut Pertanian Bogor, "Potensi, Preferensi, dan Perilaku Masyarakat terhadap Bank Syariah di Wilayah Sumatera Selatan 2004." www.bi.go.id

Bank Indonesia dan Center for Banking Research Universitas Andalas, "Identfikasi Faktor Penentu Keputusan
Konsumen dalam Memilih Jasa Perbankan, Bank Syariah versus Bank Konvensional," www.bi.go.id

Bank Indonesia. 2012. Kajian Model Bisnis Perbankan Syariah. www.bi.go.id

Bank Indonesia. 2015. Data BI Rate Januari 2009 sampai dengan Desember 2014. www.bi.go.id

Boediono. 1998. Ekonomi Moneter, Seri Sinopsis Pengantar Imu Ekonomi. Yogyakarta: BPFE

Greuning, Van Hennie dan Zamir labal. 2008. Risk Analysis For Islamic Banks. Washington DC: Ze World Bank

Gujarati, Damodar. 2003. Basic Econometri. New York: Ze Mc Graw-Hill Companes, Inc.

Gujarati, Damodar. 2012. Dasar-Dasar Ekonometrika. Jakarta: Salemba Empat

Haron, Sudin dan Norafifah Ahmad. 2000. Ze Effecs of Conventional Interest Rates and Rate of Profit on Funds Deposited Wiz Islamic Banking system in Malaysia, International Journal of Islamic Financial Service Vol. 1 No. 4

Kasmir. 2000. Manajemen Perbankan. Jakarta: Rajawali Pres

Kasmir. 2002. Dasar-Dasar Perbankan. Jakarta: Rajawali Pres

Kasri, Rahmatina \& Salina Kassim. 2009. Empirical Determinans of saving in ze Islamic Banks: Evidence from Indonesia. King Abdul Azis University. Vol 22.

Khalwati, Tajul. 2000. Inflasi dan Solusinya. Jakarta: PT Gramedia Pustaka Umum

Kotler, Philip dan Keller K Lane. 2006. Manajemen Pemasaran Edisi 11. Jakarta: PT. Indeks

Latumaerissa, Julius R. 2011. Bank dan Lembaga Keuangan lain. Jakarta: Salemba Empat

Machmud, Amir dan Rukmana. 2010. Bank Syariah (Teori, Kebijakan, dan Studi Empiris Di Indonesia). Jakarta: Penerbit Erlangga

Mannan, M. Abdul. 1997. Teori dan Praktek Ekonomi Islam. Terjemahan. Yogyakarta: Dana Bhakti Wakaf

Muflih, Muhammad. 2006. Perilaku Konsumen dalam Perspektif Ekonomi Islam. Jakarta: PT. Raja Grafindo Prasaja

Muhammad. 2004. Manajemen Dana Bank Syariah. Yogyakarta: Penerbit EKONISIA

Nopirin. 2002. Ekonomi Moneter edisi keempat. Yogyakarta: BPFE 
Pratiwi, et al/Jurnal Ekonomi Syariah Teori dan Terapan Vol. 4 No. 2 Februari 2017: 89-100; BANK SYARIAH DI INDONESIA: ANALISIS PENGARUH RATA-RATA TINGKAT BAGI HASIL DEPOSITO DAN RATA-RATA TINGKAT SUKU BUNGA DEPOSITO TERHADAP JUMLAH DEPOSITO DAN JUMLAH NASABAH DEPOSITO PERIODE 2009-2014

Otoritas Jasa Kevangan. 2015. Laporan Statistik Perbankan Syariah Edisi Januari 2011 sampai dengan Desember 2014. www.ojk.go.id

Ryandono, M. Nafik. 2009. Bursa Efek dan Investasi Syariah. Jakarta: PT Serambi Ilmu Semesta.

Samuelson, Paul A. and William D. Nordhaus. 2010. Economics. Nineteenz Edition. Singapore: McGraw-Hill

Simamora, Henry. 2004. Manajemen Sumber Daya Manusia. Edisi Ketiga Cetakan Pertama. Jakarta: Penerbit Kencana

Soemitra, Andri. 2009. Bank dan Lembaga Kevangan Syariah. Jakarta: Prenada Media

W, Muhammad Ghafur. 2003. Pengaruh Tingkat Bagi Hasil, Suku Bunga, dan Pendapatan Terhadap Simpanan Mudharabah di Bank Syariah, Studi Kasus di BMI. Jurnal Ekonomi Syariah Muamalah, Vol. 1 No. 1, hlm. 21-22.

Wardani, Elfrida Kusuma. 2015. Pengaruh Tingkat Suku Bunga Bank Inodesia (BI Rate), Indeks Produksi Industri (IPI), dan Jaringan Kantor Bank Syariah Terhadap Penghimpunan Dana Pihak Ketiga Perbankan Syariah di Indonesia. Skripsi tidak diterbitkan. Surabaya: Program Sarjana Ekonomi Islam Universitas Airlangga

Widarjono, Agus. 2007. Ekonometrika dan Aplikasinya. Yogyakarta: BPFE

Wigati, Sri. 2011 . Perilaku Konsumen Dalam Perspektif Ekonomi Islam. Jurnal Maliyah (Online), Vol. 1, No. 1

Wirdyaningsih. 2005. Bank dan Asuransi Islam Di Indonesia. Jakarta: Prenada Media

Yusoff, Remali dan Rodney Wilson. 2005. An Economic Analysis of Conventional and Islamic Bank Deposis in Malaysia, Review of Islamic Economics, Vol. 9, No. 1,2005

Zainol, Zairy dan Salina H Kassim. 2010. An Analysis of Islamic Bank's Exposure to Rate of Return Risk, Journal of Economic Cooperation and Development, 31, 1 (2010),59 